\title{
Manganese and Cadmium Benzoate Complexes Having 8-Aminoquinoline Ancillary Ligand
}

\author{
Abhilasha Mohan Baruah, Anirban Karmakar and Jubaraj Bikash Baruah* \\ Department of Chemistry, Indian Institute of Technology Guwahati, Guwahati 781039 Assam, India
}

\begin{abstract}
Simple synthetic methods for synthesis of trinuclear manganese(II) benzoate complexes having 8aminoquinoline as ancillary ligand are reported. The crystal structure of two trinuclear manganese(II) complexes, [ $\mathrm{Mn}_{3}(2-$ $\left.\left.\mathrm{NO}_{2} \mathrm{C}_{6} \mathrm{H}_{4} \mathrm{COO}\right)_{6}(\mathrm{AQ})_{2}\right](\mathbf{I})$ and $\left[\mathrm{Mn}_{3}\left(3-\mathrm{CH}_{3} \mathrm{C}_{6} \mathrm{H}_{4} \mathrm{COO}\right)_{6}(\mathrm{AQ})_{2}\right]$. NPD (II) is reported (where AQ = 8-aminoquinoline, NPD $=1,5$ dihydroxynaphthalene). In solution, the degradation of trinuclear complex $\mathbf{I}$ leads to a dinuclear complex $\left[\mathrm{Mn}_{2}(2-\right.$ $\left.\left.\mathrm{NO}_{2} \mathrm{C}_{6} \mathrm{H}_{4} \mathrm{COO}\right)_{4}(\mathrm{AQ})_{2}\left(\mathrm{H}_{2} \mathrm{O}\right)_{2}\right]$ (III) and structure of complex III is reported. A solution phase synthetic method for the synthesis of the dinuclear manganese(II) complex III is also reported. This complex has a $\mathrm{Mn}_{2} \mathrm{O}_{2}$ bridge originating from the carboxylate ligand. Synthesis of a cadmium 2-nitrobenzoate co-ordination polymer $\left[\mathrm{Cd}\left(2-\mathrm{NO}_{2} \mathrm{C}_{6} \mathrm{H}_{4} \mathrm{COO}\right)_{2}(\mathrm{AQ})\right]_{\mathrm{n}}(\mathbf{I V})$ having eight co-ordination number is reported and its structure is explained as aggregation of multiple numbers of six coordinated mononuclear cadmium complexes.
\end{abstract}

Keywords: Metal carboxylates, 8-aminoquinoline, manganese trinuclear complexes, cadmium co-ordination polymer.

\section{INTRODUCT ION}

Carboxylate ligands can bind to metal ions in several ways, such as monodentate, bidentate, bridging etc. These binding modes complicate selective synthesis of metal carboxylate complexes [1-12]. A general approach to rationalize selective synthetic procedures for polynuclear carboxylate complexes would require extensive structural study on carboxylate complexes prepared via different synthetic routes [13-25]. Retro-analysis of structures of polynuclear metal complexes provides information on the smallest mononuclear building blocks to form assemblies [26]. Such approach is applied to carboxylate complexes that are prepared through hydrothermal method. Comparison of structure of complexes prepared through solution route or some other related methods is essential to understand nucleation process. It is necessary to choose ligand that has versatility to form different types of metal complexes [27-33]. There is vast literature on mononuclear and polynuclear metal carboxylate complexes [13-25, 34], thus the metal carboxylate complexes would be suitable for such study. The rationalization of the structural aspect through co-ordination capability of the metal ions can be another approach to standardize synthetic procedures. In this study the synthesis and structures of the trinuclear manganese complexes, and co-ordination polymer of cadmium having 8-aminoquinoline (AQ) are reported.

\section{MATERIALS AND METHODS}

\subsection{Synthesis and Spectroscopic Properties of Complexes}

\subsection{1. $\left[\mathrm{Mn}_{3}\left(2-\mathrm{NO}_{2} \mathrm{C}_{6} \mathrm{H}_{4} \mathrm{COO}\right)_{6}(\mathrm{AQ})_{2}\right](\mathrm{I})$}

Manganese acetate tetrahydrate $(0.245 \mathrm{~g}, 1 \mathrm{mmol})$ and 2-nitrobenzoic acid $(0.334 \mathrm{~g}, 2 \mathrm{mmol})$ were mixed in a mor-

*Address correspondence to this author at the Department of Chemistry, Indian Institute of Technology Guwahati, Guwahati 781039 Assam, India; E-mail: juba@iitg.ernet.in tar and heated at $80^{\circ} \mathrm{C}$ in an oven for $20 \mathrm{~min}$. The mixture was cooled and it was slowly added to a methanol solution of 8 -aminoquinoline $(0.288 \mathrm{~g}, 2 \mathrm{mmol}$ in $10 \mathrm{ml})$ and stirred for five minutes. To this solution, toluene $(5 \mathrm{ml})$ was added and a green homogeneous solution was obtained. The solution was kept for crystallization. After three days, dark brown crystals appeared (76\% yield). Elemental anal calcd for $\mathrm{C}_{60} \mathrm{H}_{40} \mathrm{Mn}_{3} \mathrm{~N}_{10} \mathrm{O}_{24} ; \mathrm{C}, 49.65 ; \mathrm{H}, 2.76$; found $\mathrm{C}, 50.72, \mathrm{H}$, 2.77. IR (KBr, $\left.\mathrm{cm}^{-1}\right)$ : 3293(bw), 1624(s), 1527(s), 1378(s), 1143(w), 1076(w), 979(m), 840(m), 774(m), 568(m). Molar Conductance: $118.00 \mathrm{~mol}^{-1} \mathrm{~m}^{2} \mathrm{~S}$ in methanol; $5.4 \mathrm{~mol}^{-1} \mathrm{~m}^{2} \mathrm{~S}$ in acetonitrile; $33.2 \mathrm{~mol}^{-1} \mathrm{~m}^{2} \mathrm{~S}$ in $\mathrm{N}, \mathrm{N}^{\prime}$ - dimethyl-formamide. LC-MS $\left(\mathrm{CH}_{3} \mathrm{CN} / \mathrm{HCOOH}, \mathrm{m} / \mathrm{e}\right)$ 944.97, 902.04, 391.03.

\subsection{2. $\left[\mathrm{Mn}_{3}\left(3-\mathrm{CH}_{3} \mathrm{C}_{6} \mathrm{H}_{4} \mathrm{COO}\right)_{6}(\mathrm{AQ})_{2}\right] \mathrm{NPD}(\mathrm{II})$ (where $\mathrm{NPD}$ is 1,5-naphthalenediol)}

A mixture of manganese(II) acetate tetrahydrate $(0.245 \mathrm{~g}$, $1 \mathrm{mmol})$ and 3-methylbenzoic acid $(0.272 \mathrm{~g}, 2 \mathrm{mmol})$ was taken in a mortar and powdered. The powder was heated at $80^{\circ} \mathrm{C}$ in an oven for $20 \mathrm{~min}$. The mixture was then cooled and it was added to a methanol solution of 8-aminoquinoline $(0.144 \mathrm{~g}, 1 \mathrm{mmol}, 10 \mathrm{ml}$ methanol) and stirred for five minutes. A toluene solution of 1,5-naphthalenediol ( $1 \mathrm{mmol}$ in 5 $\mathrm{ml}$ toluene) was added to this. The solution became completely homogeneous. The green colored solution was kept for crystallization. After seven days, dark brown crystals of complex II appeared (78\% yield). Elemental anal calcd for $\mathrm{C}_{76} \mathrm{H}_{66} \mathrm{Mn}_{3} \mathrm{~N}_{4} \mathrm{O}_{14} ; \mathrm{C}, 64.03 ; \mathrm{H}, 4.63$; found $\mathrm{C}, 64.00, \mathrm{H}, 4.62$. $\mathrm{IR}\left(\mathrm{KBr}, \quad \mathrm{cm}^{-1}\right) \quad 3416(\mathrm{~m}), \quad 3293(\mathrm{~m}), \quad 3196(\mathrm{w}), \quad 3135(\mathrm{w})$, 3063(w), 2919(m), 2858(w), 2351(w), 1931(w), 1726(s), 1614(s), 1568(m), 1516(s), 1393(s), 1286(w), 1224(w), 1081(s), 1035(s), 902(m), 758(s), 677(s). Molar Conductance: $93.8 \mathrm{~mol}^{-1} \mathrm{~m}^{2} \mathrm{~S}$ in methanol; $4.5 \mathrm{~mol}^{-1} \mathrm{~m}^{2} \mathrm{~S}$ acetonitrile and $10.2 \mathrm{~mol}^{-1} \mathrm{~m}^{2} \mathrm{~S}$ in $\mathrm{N}, \mathrm{N}^{\prime}$ - dimethylformamide. Magnetic moment 5.62 $\mathrm{BM}$ at $28^{\circ} \mathrm{C}$. Uv-vis (methanol) $460 \mathrm{~nm}(99$ $\left.\mathrm{mol}^{-1} \mathrm{~cm}^{2}\right)$. 
Table 1. Crystallographic Parameter of Complexes I-IV

\begin{tabular}{|c|c|c|c|c|}
\hline Compound No. & $\mathbf{I}$ & II & III & IV \\
\hline Formulae & $\mathrm{C}_{60} \mathrm{H}_{40} \mathrm{Mn}_{3} \mathrm{~N}_{10} \mathrm{O}_{24}$ & $\mathrm{C}_{76} \mathrm{H}_{66} \mathrm{Mn}_{3} \mathrm{~N}_{4} \mathrm{O}_{14}$ & $\mathrm{C}_{46} \mathrm{H}_{36} \mathrm{Mn}_{2} \mathrm{~N}_{8} \mathrm{O}_{18}$ & $\mathrm{C}_{23} \mathrm{H}_{16} \mathrm{Cd} \mathrm{N}_{4} \mathrm{O}_{8}$ \\
\hline Crystal system & Triclinic & Triclinic & Monoclinic & Triclinic \\
\hline Space group & $\mathrm{P}-1$ & $\mathrm{P}-1$ & $\mathrm{P} 2(1) / \mathrm{c}$ & $\mathrm{P}-1$ \\
\hline$b / \AA$ & $12.0984(4)$ & $12.0233(16)$ & $21.607(3)$ & $13.0732(3)$ \\
\hline$c / \AA$ & $12.2235(4)$ & $14.0041(19)$ & $14.434(2)$ & $13.8012(3)$ \\
\hline$\alpha /^{\circ}$ & 99.997(2) & $102.924(8)$ & 90.00 & $112.2320(10)$ \\
\hline$\beta /^{\circ}$ & $100.682(2)$ & $92.322(8)$ & $97.215(11)$ & $102.4910(10)$ \\
\hline $\mathrm{Z}$ & 1 & 1 & 2 & 2 \\
\hline Density $/ \mathrm{Mgm}^{-3}$ & 1.592 & 1.367 & 1.537 & 1.705 \\
\hline Abs. Coeff. $/ \mathrm{mm}^{-1}$ & 0.711 & 0.607 & 0.618 & 1.010 \\
\hline Abs. correction & none & none & none & none \\
\hline $\mathrm{F}(000)$ & 737 & 737 & 1124 & 588 \\
\hline Total no. of reflections & 16914 & 25628 & 16672 & 16490 \\
\hline Reflections, $I>2 \sigma(I)$ & 7075 & 8437 & 5340 & 5403 \\
\hline $\mathrm{R}$ indices (all data) & 0.0489 & 0.1334 & 0.1830 & 0.0351 \\
\hline
\end{tabular}

\subsection{3. $\left[\mathrm{Mn}_{2}\left(2-\mathrm{NO}_{2} \mathrm{C}_{6} \mathrm{H}_{4} \mathrm{COO}\right)_{4}(\mathrm{AQ})_{2}\left(\mathrm{H}_{2} \mathrm{O}\right)_{2}\right](\mathrm{III})$}

The complex III was obtained by slow evaporation of a dilute solution of $\mathbf{I}$ in methanol ( 5 days) as a side product.

\section{Alternative Procedure}

A solution of manganese acetate tetrahydrate $(0.245 \mathrm{~g}, 1$ mmol) and of 2-nitrobenzoic acid (0.334 g, $2 \mathrm{mmol})$ was prepared in methanol and stirred for two hours, to this solution a methanol solution of 8-aminoquinoline $(0.144 \mathrm{~g}, 1$ mmol in $10 \mathrm{ml}$ ) was added and stirred for $24 \mathrm{~h}$. The solution was filtered to remove any residue remaining and left for crystallization for 4 days. Brownish crystals of III were collected by filtration.

Yield 67\%. Elemental anal calcd for $\mathrm{C}_{46} \mathrm{H}_{36} \mathrm{Mn}_{2} \mathrm{~N}_{8} \mathrm{O}_{18} ; \mathrm{C}$, 50.24; H,3.28; found C, 50.46; H, 3.31. H, 3.31. IR ( $\mathrm{KBr}$, $\left.\mathrm{cm}^{-1}\right)$ 3410(s), 3308(s), 1629(s), 1609 (s), 1571(s), 1540(s), 1521(s), 1503(s), 1388(s), 1366(s), 1347(s), 989(s), 825(s), 786(s), 738(s), 697(s), 646(s). Molar conductance: $98.5 \mathrm{~mol}^{-}$
${ }^{1} \mathrm{~m}^{2} \mathrm{~S}$ methanol. Magnetic moment $5.58 \mathrm{BM}$ at $28^{\circ} \mathrm{C}$. UV-V is (methanol) $460 \mathrm{~nm}\left(\varepsilon=99 \mathrm{~mol}^{-1} \mathrm{~cm}^{2}\right)$. LC-MS (DMSO, m/e) 582.54

\subsection{4. $\left[\mathrm{Cd}\left(2-\mathrm{NO}_{2} \mathrm{C}_{6} \mathrm{H}_{4} \mathrm{COO}\right)_{2}(\mathrm{AQ})\right]_{n}(\mathrm{IV})$}

Cadmium acetate dihydrate $(0.266 \mathrm{~g}, 1 \mathrm{mmol})$ and 2nitrobenzoic acid $(0.334 \mathrm{~g}, 2 \mathrm{mmol})$ were mixed in a mortar and heated in an oven at $70^{\circ} \mathrm{C}$ for 30 minutes. The mixture was then cooled and transferred to a round bottomed flask. To this, methanol $(10 \mathrm{ml})$ and toluene $(5 \mathrm{ml})$ was added and stirred. Then, 8-aminoquinoline $(0.288 \mathrm{~g}, 2 \mathrm{mmol})$ was added and stirred for $30 \mathrm{~min}$. The solution on standing for three days crystallises IV as light green crystals. Yield $80 \%$. Elemental anal calcd for $\mathrm{C}_{23} \mathrm{H}_{16} \mathrm{Cd} \mathrm{N}_{4} \mathrm{O}_{8} ; \mathrm{C}, 46.88 ; \mathrm{H}, 2.72$; found $\mathrm{C}, 47.01, \mathrm{H}, 2.71$. LC-MS (acetonitrile/formic acid, $\mathrm{m} / \mathrm{e}) 637,638,639,640,641 . \operatorname{IR}\left(\mathrm{KBr}, \mathrm{cm}^{-1}\right)$ 3401(bw), 1639(s), 1516(m), 1388(s), 1153(w), 1076(w), 846(w), 641(w). ${ }^{1} \mathrm{HNMR}\left(\mathrm{DMSO}_{\mathrm{d}}\right)$ 5.91(bs, 2H), 6.86(d, J=8Hz, $1 \mathrm{H}), 7.06(\mathrm{~d}, \mathrm{~J}=8 \mathrm{~Hz}, 1 \mathrm{H}), 7.30(\mathrm{t}, \mathrm{J}=8 \mathrm{~Hz}, 1 \mathrm{H}), 7.46(\mathrm{~m}, 1 \mathrm{H})$ 
7.59-7.72 (m, 4H), 7.74(d, J=8Hz, 2H), $7.85(\mathrm{~d}, \mathrm{~J}=8 \mathrm{~Hz}, 2 \mathrm{H})$, $8.18(\mathrm{~d}, \mathrm{~J}=8 \mathrm{~Hz}, 1 \mathrm{H}), 8.72(\mathrm{~s}, 1 \mathrm{H})$.

\subsection{X-Ray Crystallography}

The X-ray diffraction data were collected at room temperature on a Bruker 3-circle diffractometer (Bruker Nonius SMART APEX 2) equipped with CCD area detectors, and using graphite-monochromated Mo $K_{\alpha}$ radiation $(\lambda=$ $0.71073 \AA$ ) from $60 \mathrm{~W}$ micro focus Siemens Microsource with glass polycapillary optics. X-ray diffraction data for all the crystals were collected using Bruker SMART software. This software was also used for indexing and determining the unit cell parameters. The structures were solved by direct methods and refined by full-matrix least squares against $F^{2}$ for all data using SHELXTL software. All non-H atoms were refined by full-matrix least squares in the anisotropic approximation and the hydrogen atoms attached to these atoms are located on the difference Fourier maps and refined in the final structure in isotropic approximation. The crystal data of the structures of the compounds are listed in Table $\mathbf{1 .}$

\section{RESULTS AND DISCUSSION}

A solid phase reaction of manganese(II) acetate tetrahydrate with 2-nitrobenzoic acid followed by reaction with 8aminoquinoline in solution gives a trinuclear manganese complex (Eqn 1). Similar reaction of benzoic acid, 3methylbenzoic acid, 4-chlorobenzoic acid also gave trinuclear manganese complexes. However, in the case of 3methylbenzoic acid and 4-chlorobenzoic acid we could crystallize the trinuclear complexes as co-crystal with 1,5naphthalenediol. Since complexes are iso-structural of the structure of I and II, two representative structures of the complexes are given in Fig. (1).

$3 \mathrm{Mn}(\mathrm{OAC})_{2} \cdot 4 \mathrm{H}_{2} \mathrm{O}+6 \mathrm{RCOOH}+2 \mathrm{AQ} \longrightarrow\left[\mathrm{Mn}_{3}(\mathrm{RCOO})_{6}(\mathrm{AQ})_{2}\right]+6 \mathrm{AcOH}+12 \mathrm{H}_{2} \mathrm{O}$

$$
\mathrm{R}=2-\mathrm{NO}_{2} \mathrm{C}_{6} \mathrm{H}_{4}(\mathbf{I}) ; 3-\mathrm{CH}_{3} \mathrm{C}_{6} \mathrm{H}_{4}-(\mathrm{II}), \mathrm{AQ}=8 \text {-aminoquinoline }
$$

\section{Equation 1.}

In these complexes all the manganese centers are in distorted octahedral geometry. The central manganese (II) is coordinated to six oxygen atoms from the carboxylate ligands. The carboxylate ligands attached to the central metal atom are connected through two different types of bridges.
One of the bridges is conventional carboxylate bridge that is found in paddle wheel structures and other is through uniunidentate carboxylate bridge leading to Mn-O-Mn type of interactions. This type of carboxylate bridge occurs as complementing mode $[2,27]$ to chelating mode of carboxylate binding, associated with parent carboxylic unit to another metal ion. Two other manganese ions at the two ends of the trinuclear manganese complex are symmetric to each other and both has distorted octahedral environment. Such octahedral environments are generated by a chelating carboxylate and two oxygen of bridging carboxylates that are involved in bridging the central manganese. In addition to these the amino group and the nitrogen atom of 8-aminoquinoline coordinate to form five member chelate structure. Selected bond distances of $\mathbf{I}$ and $\mathbf{I I}$ are shown in Table $\mathbf{2}$ and $\mathbf{3}$, respectively. The molar conductance of the solution of $I$ is solvent dependent, for example the values are $118.0 \mathrm{~mol}^{-}$ ${ }^{1} \mathrm{~m}^{2} \mathrm{~S}$ in methanol; $5.4 \mathrm{~mol}^{-1} \mathrm{~m}^{2} \mathrm{~S}$ in acetonitrile; $33.2 \mathrm{~mol}^{-}$ ${ }^{1} \mathrm{~m}^{2} \mathrm{~S}$ in $\mathrm{N}, \mathrm{N}^{\prime}$-dimethyl formamide. The low value of molar conductance in aprotic medium and higher value in protic medium suggests that protic solvent dissociates the complex. In solution the complex I shows highest mass for hydrated dinuclear species. The room temperature magnetic susceptibility value per manganese for the complexes I, II and III is 5.69 and 5.62 and 5.58 BM, respectively, which are slightly lower than the spin only values for five unpaired electrons for $\mathrm{d}^{5}$ systems. We have also measured the magnetic susceptibility in the range of temperature, ranges of 50-300K show exponential decrease with anti-ferromagnetic characteristic, but the $1 / \lambda$ vs. temperature plots are not very smooth to give quantitative values.

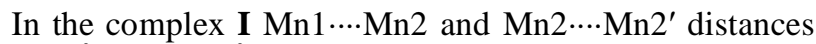
are $3.63 \AA$ and $7.25 \AA$ respectively, whereas in the complex II the $\mathrm{Mn} 1 \cdots \mathrm{Mn} 2$ and $\mathrm{Mn} 2 \cdots \cdot \mathrm{Mn} 2^{\prime}$ distances are $3.58 \AA$ and $7.16 \AA$, respectively. The large separations are indicative of very weak or no metal-metal interactions. Few manganese complexes of 8-aminoquinoline are known in literature [35] and it was suggested that the ligand becomes susceptible toward oxidation on complexation to manganese. In contrast, our complexes are stable in solid state. However, long standing of a methanol solution of $\mathbf{I}$ gave a dinuclear complex III with a composition $\quad\left[\mathrm{Mn}_{2}\left(2-\mathrm{NO}_{2} \mathrm{C}_{6} \mathrm{H}_{4} \mathrm{COO}\right)_{4}\right.$

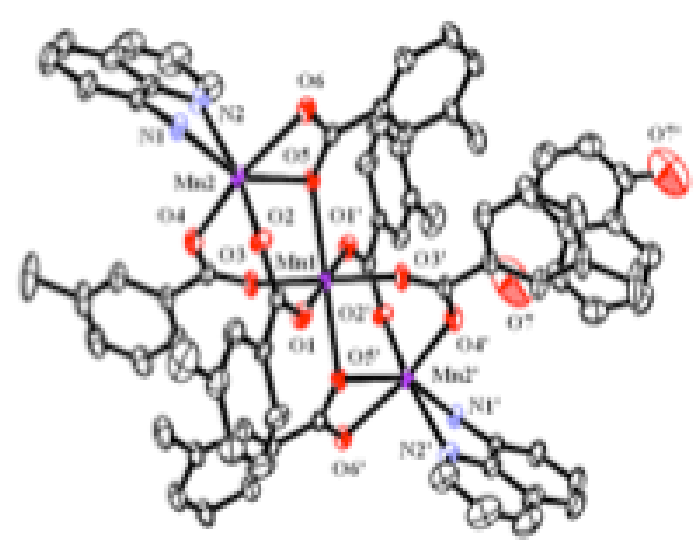

(b)

Fig. (1). Structure of trinuclear manganese complex (a) I and (b) II (drawn with $20 \%$ ellipsoid probability and hydrogen atoms are omitted for clarity). 
Table 2. Selected Inter-Nuclear Distances (in $\AA$ ) and Angles (in ${ }^{\circ}$ ) in I

\begin{tabular}{|c|c|c|c|c|c|}
\hline $\mathrm{Mn} 1-\mathrm{O} 1$ & 2.12 & $\mathrm{O} 2-\mathrm{Mn} 2-\mathrm{O} 6$ & 101.48 & N1-Mn2- O9 & 98.88 \\
\hline Mn1-O9 & 2.25 & $\mathrm{O} 2-\mathrm{Mn} 2-\mathrm{O} 9$ & 95.30 & N1-Mn2- O10 & 87.13 \\
\hline $\mathrm{Mn} 2-\mathrm{O} 9$ & 2.24 & O6- Mn2- O9 & 96.22 & O1-Mn1-O9 & 91.83 \\
\hline Mn2-O10 & 2.37 & O6- Mn2- N2 & 86.47 & O5- Mn1- O9 & 92.15 \\
\hline $\mathrm{Mn} 2-\mathrm{N} 1$ & 2.24 & O6 -Mn2- N1 & 156.59 & O5 -Mn1- O9 & 87.85 \\
\hline
\end{tabular}

Table 3. Selected Inter-Nuclear Distances (in $\AA$ ) and Angles (in ${ }^{\circ}$ ) in II

\begin{tabular}{|c|c|c|c|c|c|}
\hline $\mathrm{Mn} 1-\mathrm{O} 1$ & 2.20 & O1-Mn1-O5 & 93.33 & $\mathrm{O} 2-\mathrm{Mn} 2-\mathrm{N} 2$ & 163.94 \\
\hline Mn1-O5 & 2.25 & O3 -Mn1- O5 & 87.90 & O4-Mn2-O5 & 102.16 \\
\hline $\mathrm{Mn} 2-\mathrm{O} 2$ & 2.10 & O3- Mn1-O5' & 92.10 & $\mathrm{O} 4-\mathrm{Mn} 2-\mathrm{N} 1$ & 102.94 \\
\hline Mn2-O5 & 2.24 & O3- Mn1-O1' & 91.60 & $\mathrm{O} 4-\mathrm{Mn} 2-\mathrm{N} 2$ & 86.23 \\
\hline $\mathrm{Mn} 2-\mathrm{O} 6$ & 2.28 & O3-Mn1-O1 & 91.60 & O5-Mn2- N1 & 152.57 \\
\hline Mn2-N1 & 2.25 & O3- Mn1-O5 & 92.11 & O5- Mn2- O6 & 58.12 \\
\hline $\operatorname{Mn}(1) \cdots \operatorname{Mn}(2)$ & & $\mathrm{O} 2-\mathrm{Mn} 2-\mathrm{O} 6$ & 91.13 & N1-Mn2-O6 & 95.73 \\
\hline
\end{tabular}

$\left.(\mathrm{AQ})_{2}\left(\mathrm{H}_{2} \mathrm{O}\right)_{2}\right]$. This dinuclear complex can alternatively prepared by reaction of manganese acetate with 2-nitrobenzoic acid with 8-aminoquinoline in methanol solution. In this reaction exclusive formation of III was observed. Structure of this complex is shown in Fig. (2). In methanol solution the complex is not stable and LC-MS in solution shows that the complex decomposes to $\left[\mathrm{Mn}(\mathrm{AQ})_{2}\left(2-\mathrm{NO}_{2} \mathrm{C}_{6} \mathrm{H}_{4} \mathrm{COO}\right)_{2}\right](\mathrm{m} / \mathrm{e}$ 688.45 ) in addition to the mono-nuclear complex having $\mathrm{m} / \mathrm{z}$ 582.4; whereas in dimethylsulphoxide solution it shows mass of the mononuclear form $\left[\mathrm{Mn}(\mathrm{AQ})\left(2-\mathrm{NO}_{2} \mathrm{C}_{6} \mathrm{H}_{4} \mathrm{COO}\right)_{2}\right.$ $\left.\left(\mathrm{H}_{2} \mathrm{O}\right)_{2}\right](\mathrm{m} / \mathrm{e}$ 582.54). This complex is structurally important as it has novel $\mathrm{Mn}_{2} \mathrm{O}_{2}$ type of skeleton arising out of carboxylate bridges and these types of molecules are not encountered as independent species. But such bridges are ob- served in constrained environment such as co-ordination polymers [27]. In complex III the manganese centers have distorted octahedral geometry formed by two oxo-bridged uni-uni dentate carboxylate groups and chelate from the 8aminoquinoline and a monodetate carboxylate and an aqua ligand. Some of the selected bond distances of the complex are Mn1-O3, 2.123(3); Mn1-O1, 2.181(3); Mn1-O9, 2.188(2); Mn1-O1, 2.224(2); Mn1-N3, 2.226(4); Mn1-N4, $2.243(3) \AA$. In this complex, Mn....Mn distance is $3.334 \AA$. Selected bond distances and bond angles are listed in Table 3. The complex III has IR absorptions that clearly distinguish it from the IR of complex I. It has sharp absorption at $3410 \mathrm{~cm}^{-1}$ due to the terminal aqua ligands, such absorption is absent in trinuclear species. 


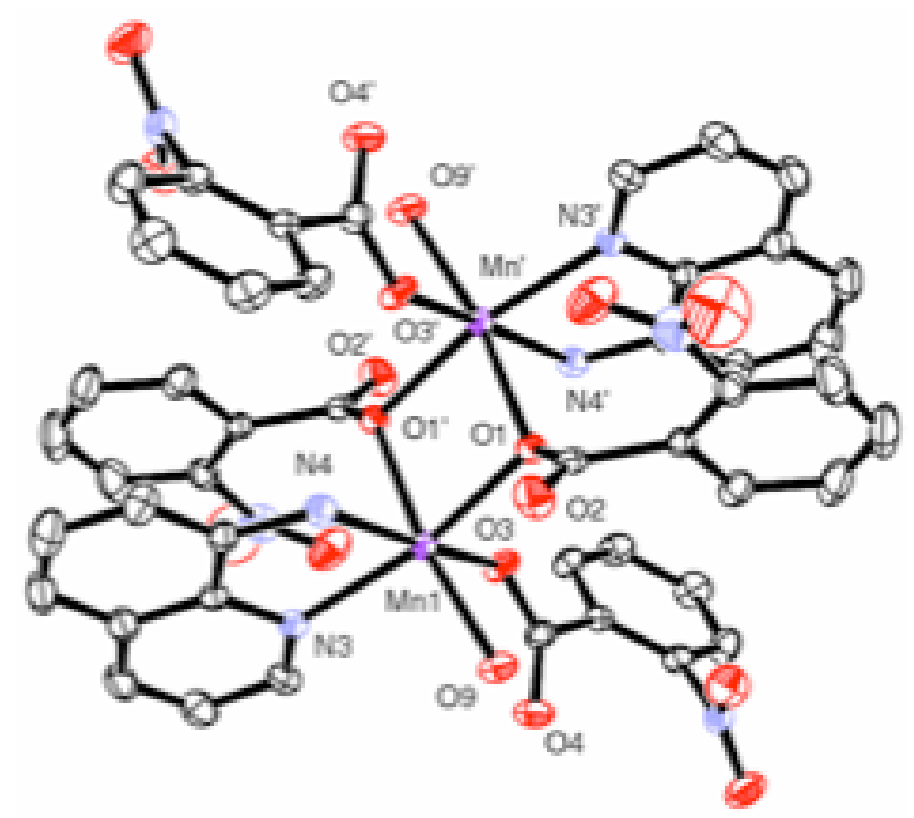

Fig. (2). Structure of dinuclear manganese complex III (drawn with $20 \%$ ellipsoid probability and hydrogen atoms are omitted for clarity).

Table 4. Selected Inter-Nuclear Distances (in $\AA$ ) and Angles (in ${ }^{\circ}$ ) in III

\begin{tabular}{|c|c|c|c|c|c|}
\hline Mn1-O1 & 2.18 & O1-Mn1-O1' & 81.62 & O3-Mn1-O4 & 172.22 \\
\hline $\mathrm{Mn} 1-\mathrm{O} 3$ & 2.12 & O1-Mn1- O9 & 169.86 & O9-Mn1-N3 & 94.79 \\
\hline Mn1-N4 & 2.24 & O3-Mn1-O1' & 89.09 & N3-Mn1- O1' & 166.97 \\
\hline \multirow[t]{2}{*}{ Mn1 $\cdots$ Mn1' } & 3.33 & O3-Mn1-O9 & 87.22 & $\mathrm{~N} 4-\mathrm{Mn} 1-\mathrm{O} 1^{\prime}$ & 93.05 \\
\hline & & O3-Mn1-N3 & 102.60 & & \\
\hline
\end{tabular}

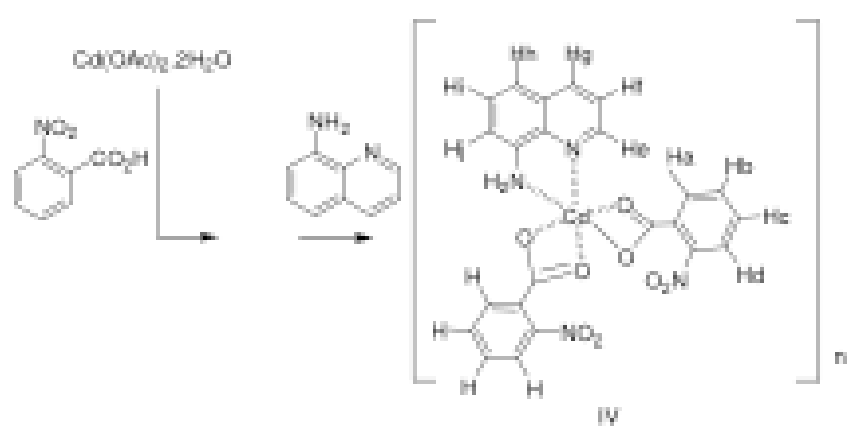

Equation 2.

A large number of structural variations can be made in cadmium complexes by varying ligands [34]. We have found that the reaction of 8-aminoquinoline with cadmium(II)acetate and 2-nitrobenzoic acid (Eqn 2) formed a co-ordination polymer. The polymer $\left[\mathrm{Cd}\left(2-\mathrm{NO}_{2} \mathrm{C}_{6} \mathrm{H}_{4} \mathrm{COO}\right)_{2}\right.$ $(\mathrm{AQ})]_{\mathrm{n}}$ (IV) comprises of eight co-ordination geometry around cadmium ion as illustrated in Fig. (3, left). The selected bond distances and bond angles are listed in Table 5.

The ${ }^{1} \mathrm{H}$ NMR of the complex shows peaks of all the hydrogen atoms of the 8-aminoquinoline in different chemical shift positions. The structure is comprised of six-coordinated mono-nuclear units which recombine to form polynuclear eight co-ordination cadmium co-ordination polymer. The coordination polymer has bridging units that are formed through uni(unidentate) (Fig. 3, right) carboxylate bridges.

The cadmium-cadmium distances in the polymer are $4.09 \AA$ suggesting them to be far apart to have interactions between them. The mass spectrum of the cadmium complex in solution (water/acetonitrile /formic acid) shows mass of the mononuclear species at $\mathrm{m} / \mathrm{e}$ 641.62. This $\mathrm{m} / \mathrm{e}$ is attributed to a six-coordinate mononuclear cadmium complex (as illustrated in Fig. 3, right) having a water and acetonitrile ligand. The mass region of $632-644 \mathrm{~m} / \mathrm{e}$ of the spectra has peaks 

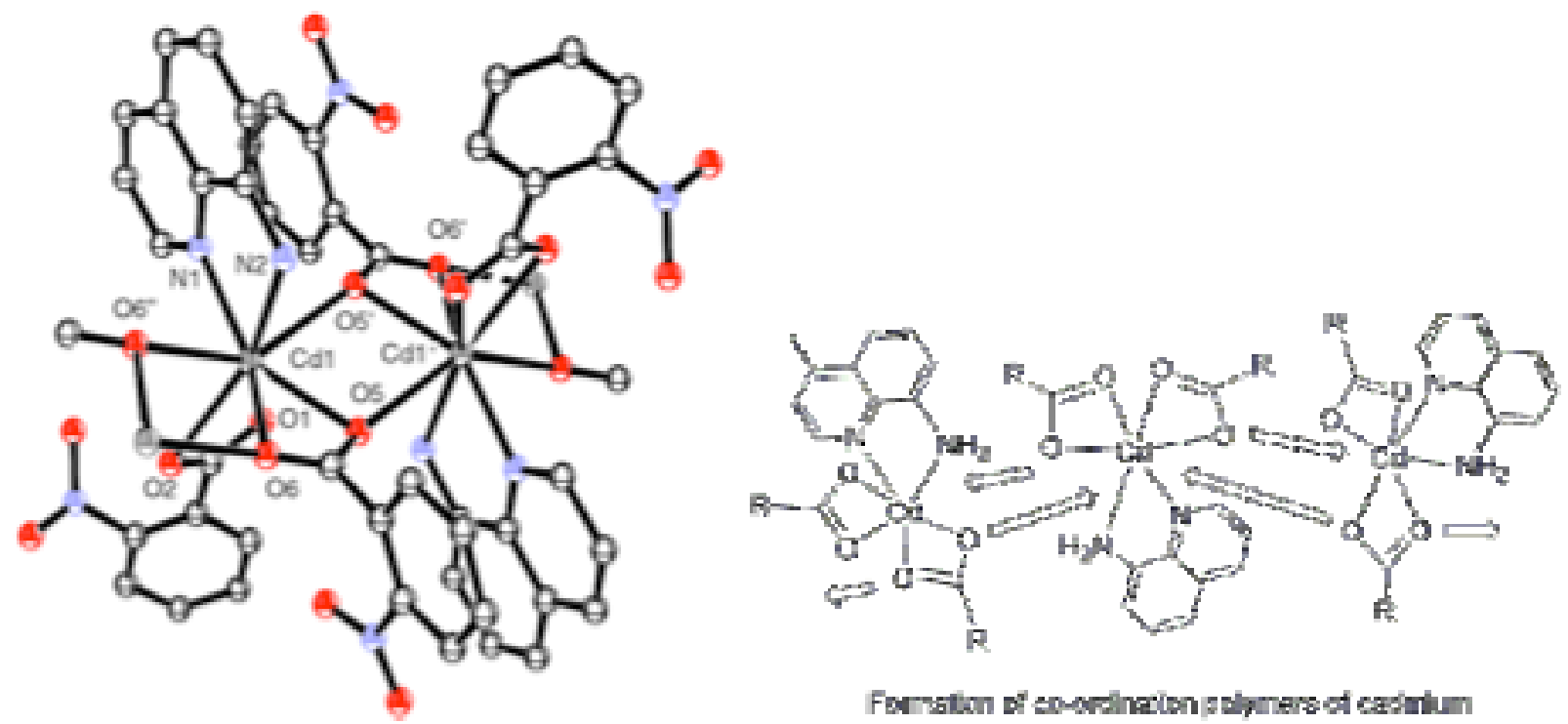

Forvation of ep-ordhailon pdlyners of casimlum

Fig. (3). Left: Two repeated units of $\left[\mathrm{Cd}\left(2-\mathrm{NO}_{2} \mathrm{C}_{6} \mathrm{H}_{4} \mathrm{COO}\right)_{2}(\mathrm{AQ})\right]_{\mathrm{n}}$ (IV); Right: Approach of mononuclear units of $[\mathrm{Cd}(2-$ $\left.\left.\mathrm{NO}_{2} \mathrm{C}_{6} \mathrm{H}_{4} \mathrm{COO}\right)_{2}(\mathrm{AQ})\right]$ to form co-ordination polymer.

Table 5. Selected Inter-Nuclear Distances (in $\AA$ ) and Angles (in ${ }^{\circ}$ ) in IV

\begin{tabular}{|c|c|c|c|c|c|}
\hline $\mathrm{Cd} 1-\mathrm{O} 1$ & 2.33 & $\mathrm{O} 1-\mathrm{Cd} 1-\mathrm{O} 2$ & 53.45 & N1-Cd1 -O1 & 97.94 \\
\hline $\mathrm{Cd} 1-\mathrm{O} 2$ & 2.51 & O1-Cd1-O6 & 112.34 & N1-Cd1-O5 & 147.81 \\
\hline Cd1-O6 & 2.59 & O1-Cd1-O6 & 129.78 & N1-Cd1-O6 & 146.56 \\
\hline Cd1-N1 & 2.29 & $\mathrm{O} 2-\mathrm{Cd} 1-\mathrm{O} 6$ & 78.50 & $\mathrm{~N} 2-\mathrm{Cd} 1-\mathrm{O} 2$ & 155.42 \\
\hline $\mathrm{Cd} 1-\mathrm{N} 2$ & 2.34 & $\mathrm{O} 5-\mathrm{Cd} 1-\mathrm{O} 2$ & 105.07 & N2- Cd1-O5 & 88.56 \\
\hline $\mathrm{Cd} 1 \cdots \mathrm{Cd} 1^{\prime}$ & 4.09 & O5-Cd1-O6 & 126.81 & $\mathrm{~N} 2-\mathrm{Cd} 1-\mathrm{O} 6$ & 76.96 \\
\hline
\end{tabular}

$\mathrm{m} / \mathrm{e} 637,638,639,640,641$ from different isomers of cadmium. Thus, clearly the co-ordination polymer of cadmium dissociates in solution to mononuclear complex.

In conclusion, we have shown that structural diversity in the carboxylate chemistry of manganese and cadmium arises from the combination of sub-units formed under various reaction conditions and thereby varieties in co-ordination complex can be obtained by varying synthetic procedure from solid- state and solution chemistry.

\section{SUPPLEMENTARY MATERIALS}

The CIF files of the structures reported here are deposited to Cambridge Crystallographic Database and have CCDC numbers 658029, 658030, 658834, 663358.

\section{ACKNOWLEDGEMENTS}

Authors thank Department of Science and Technology, New Delhi, India for financial assistance.

\section{REFERENCES}

[1] Cotton, F.A.; Lin, C.; Murillo, C. A. Acc. Chem. Res., 2001, 34, 759.

[2] Eddaoudi, M.; Moler, D.B.; Li, H.; Chen, B.; Reineke, T.M.; Keeffe, M.; Yaghi, O.M. Acc. Chem. Res., 2001, 34, 319.

[3] James, S.L. Chem. Soc. Rev., 2003, 32, 276.

[4] Murugavel, R.; Walawalkar, M.G.; Dan, M.; Roesky, H.W.; Rao, C.N.R. Acc. Chem. Res., 2004, 37, 763.

[5] Gavrilenko, K.S.; Punin, S.V.; Cador, O.; Golhen, S.; Ouahab, L.; Pavlishchuk, V.V. J. Am. Chem. Soc., 2005, 127, 12247. 
[6] Casarin, M.; Corvaja, C.; Nicola, C.D.; Falcomer, D.; Franco, L.; Monari, M.; Pandolfo, L.; Pettinari, C. ; Piccinelli, F. Inorg. Chem., 2005, 44, 6265 .

[7] Eddaoudi, M.; Li, H.; Yaghi, O.M. J. Am. Chem. Soc., 2005, 127, 7110.

[8] Kumgai, H.; Kepert, C.J.; Kurmoo, M. Inorg. Chem., 2002, 41, 3410.

[9] Barooah, N.; Sarma, R.J.; Baruah, J. B. Eur. J. Inorg. Chem., 2006, 2942.

[10] Christou, G. Acc. Chem. Res., 1989, 22, 328.

[11] Baruah, A.; Karmakar, A.; Baruah J.B. Polyhedron, 2007, 26, 4518.

[12] Baruah, A.; Karmakar, A.; Baruah J.B. Polyhedron, 2007, 26, 4479.

[13] Batten, S.R.; Robson, R. Angew. Chem. Int. Ed., 1998, 37, 1460.

[14] Yaghi, O.M.; Keeffe, M.O.; Ockwig, N.W.; Chae, H.K.; Eddaoudi, M.; Kim, J. Nature, 2003, 423, 705.

[15] Frey, G.; Serre, C.; Draznieks, C. M.; Millange, F.; Surble, S.; Dutour, J.; Margiolaki, I. Angew. Chem. Int. Ed., 2004, 43, 6296.

[16] Zhao, X.; Xiao, B.; Fletcher, A. J.; Thomas, K. M.; Bradshaw, D.; Rosseinsky, M.J. Science, 2004, 306, 1012.

[17] Moulton, B.; Zaworotko, M. J. Chem. Rev., 2001, 101, 1629.

[18] Noro, S.; Kitagawa, S.; Kondo, M.; Seki, K. Angew. Chem. Int. Ed., 2000, 39, 2081.

[19] Hagrman, P. J.; Hagrman, D.; Zubieta, J. Angew. Chem. Int. Ed., 1999, 38, 2638

[20] Seo, J. S.; Whang, D.; Lee, H.; Jun, S. I., Oh, J.; Jeon, Y. J.; Kim, K. Nature, 2000, 404, 982.

[21] Evans, O.R.; Ngo, H. L.; Lin, W. J. Am. Chem. Soc., 2001, 123, 10395.
Fang, Q. R.; Zhu, G. S.; Xue, M.; Sun, J. Y.; Wei, Y.; Qiu, S.L.; $\mathrm{Xu}, \mathrm{R}$. R. Angew. Chem. Int. Ed., 2005, 44, 3845.

[23] Xiong, R.; You, X.; Abrahams, B.; Xue, F. Z.; Che, C. Angew Chem. Int. Ed., 2001, 40, 4422

[24] Zhang, J.P.; Lin, Y.Y.; Huang, X.C.; Chen, X.M. J. Am. Chem. Soc., 2005, 127, 5495.

[25] Baca, S.G.; Reetz, M.T.; Goddard, R.; Fillippova, I.G.; Simonov, Y.A.; Gdaiec, M.; Gerbeleu, N. Polyhedron, 2006, 25, 1215.

[26] Dan, M.; Rao, C.N.R. Angew. Chem. Int. Ed., 2006, 45, 281.

[27] Delgado, F.S.; Hernandez-Molina, M.; Sanchiz, J.; Riuz-Perz, C.; Rodriguez-Martin, Y.; Lopez, T.; Lloret, F.; Julve, M. Cryst. EngComm. 2004, 6, 106.

[28] Gutchke, S. O. H.; Price, D.J.; Powell, A.K.; Wood, P.T. Eur. J. Inorg. Chem., 2001, 2739.

[29] Karmakar, A.; Sarma, R.J.; Baruah, J. B. Eur. J. Inorg. Chem., 2007, 643.

[30] Karmakar, A.; Sarma, R. J;. Baruah, J. B. Eur. J. Inorg. Chem., 2006, 4673.

[31] Barooah, N.; Karmakar, A.; Sarma, R. J.; Baruah, J. B. Inorg Chem. Commun., 2006, 9, 1251.

[32] Karmakar, A.; Bania, K.; Baruah, A.; Baruah, J.B. Inorg. Chem. Commun., 2007, $10,959$.

[33] Yu, S-B.; Lippard, S.J.; Shweky, I.; Bino, A. Inorg. Chem., 1992, 31, 3502 .

[34] Bania, K.; Barooah, N.; Baruah, J.B. Polyhedron, 2007, 26, 2612

[35] Fanning, J.C.; Taylor, L. T. J. Inorg. Nuclear Chem., 1965, 27, 2217. 